A

\title{
Rевевсн Автіск: : Study on knowledge and adoption of green gram production technology by farmers in Chhotaudaipur district of Gujarat
}

B.L. DHAYAL AND B.M. MEHTA

Article Chronicle: Received : 01.08.2015;

Revised :

01.10.2015;

Accepted :

15.10.2015

KeY Words :

Knowledge, Adoption, Green gram, Greengram Growers, Improved greengram production technology,

Cultivation office bearer of organization (25\%).
Author for correspondence :

\section{B.L. DHAYAL}

Krishi Vigyan Kendra, VADODARA (GUJARAT) INDIA

Email: dhayalextn@

yahoo.co.in

See end of the article for authors' affiliations
SUMMARY : Farmers had average knowledge about improved practices of green gram cultivation in the Chhotaudaipur district of Gujarat. Farmers possessed comparatively more knowledge about high yielding varieties and time of sowing. Minimum knowledge was possessed in plant protection measures and fertilizer application in greengram cultivation and majority of greengram growers were in medium adoption group followed by low and high adoption group. Greengram growers adopted high yielding variety, seed rate and spacing and time of sowing. Minimum adoption was found in fertilizer application and plant protection measures of improved greengram production technology. The majority of farmers belonged to the middle age group i.e., between 30-54 years. It was further found that 63.0 farmers belonged to the up to secondary category of educational level. The majority of farmers were having more than 2.00 ha land followed by small farmers and marginal farmers in the study sample. It was also found that 88.00 per cent farmers belonged to have more Rs. 24000 income per annu).The 30.00 per cent of farmers were no member of any organization followed by member of one organization $(45 \%)$ and

How to cite this article : Dhayal, B.L. and Mehta, B.M. (2015). Study on knowledge and adoption of green gram production technology by farmers in Chhotaudaipur district of Gujarat. Agric. Update, 10(4): 318-322. 